\title{
ANALISIS FAKTOR-FAKTOR YANG MEMPENGARUHI PELAKSANAAN PELAPORAN PERTANGGUNGJAWABAN DANA GEREJA MASEHI INJILI DI MINAHASA (GMIM) KOTA MANADO
}

\author{
Melisa Mouren Kalangi \\ Grace B. Nangoi \\ Lintje Kalangi \\ (Email: mel_mouren@yahoo.com)
}

\begin{abstract}
The existence of problems that often occur in public sector organizations in this church organizations (GMIM) required him to prepare an accountability report. The obligation to prepare an accountability report of the church also refers to Law No. 14 of 2008 which is an Act to regulate on Public Information Openness (KIP).

This study aims to identify and analyze whether Commitment, Human Resources, tools and motivation influential supporters Paporan Accountability Implementation Fund Evangelical Christian Church in Minahasa (GMIM) in the city of Manado, either simultaneously or partially.

The method used is multiple linear regression analysis using the equation $\mathrm{Y}=\alpha+\beta 1 \mathrm{X} 1+$ $\beta 2 \mathrm{X} 2+\beta 3 \mathrm{X} 3+\beta 4 \mathrm{X} 4+\varepsilon$, Descriptive Statistics, Test Reliability and Validity, Classical Assumption Test, among others Normality Test Data, Test autocorrelation, Test Heteroskidastity, Test multikolinearitas. Hypothesis testing using the coefficient of determination, $\mathrm{F}$ test, $\mathrm{t}$ test.

Based on $\mathrm{F}$ test showed a significance level of 0.006 is smaller than the statistical significance level of 0.05 . This shows that $\mathrm{H}_{0}$ and $\mathrm{H}_{1}$ accepted. It can be concluded that jointly commitment variable $\left(\mathrm{X}_{1}\right)$, the quality of human resources $\left(\mathrm{X}_{2}\right)$, supporting devices $\left(\mathrm{X}_{3}\right)$ and motivation $\left(\mathrm{X}_{4}\right)$ effect on the reporting of an accountability of Evangelical Christian in Minahasa Church. While based on t-test significance level of commitment variable $\left(\mathrm{X}_{1}\right)$, the quality of human resources $\left(\mathrm{X}_{2}\right)$, a support device $\left(\mathrm{X}_{3}\right)$, motivation $\left(\mathrm{X}_{4}\right)$, among others, $0.212,0.435,0.083,0.163$ greater than the statistical significance level of 0.05 . This shows that partially all variables does not affect the preparation of an accountability report of GMIM.
\end{abstract}

Keywords: Accountability of funds, Public Sector Organizations.

\section{BAB I PENDAHULUAN}

\subsection{Latar Belakang}

Gereja termasuk dalam jenis organisasi sektor publik yang tidak bertujuan mencari keuntungan melainkan untuk usaha-usaha yang bersifat sosial. Bastian (2010) menyatakan definisi organisasi sektor publik adalah organisasi yang menggunakan dana masyarakat, seperti: Organisasi Pemerintah Pusat, Organisasi Pemerintah Daerah, Organisasi Partai Politik dan Lembaga Swadaya Masyarakat, Organisasi Yayasan, Organisasi Pendidikan dan Kesehatan (puskesmas, rumah sakit, dan sekolah), Organisasi Tempat Peribadatan (masjid, gereja, vihara, kuil). Sebagai organisasi nirlaba, gereja berkewajiban dan berkepentingan untuk menyusun laporan pertanggungjawaban dana yang diperuntukkan kepada pihak-pihak yang berkepentingan terutama jemaatnya dan para donator sebagai perwujudan transparansi dan akuntabilitas pengelolaan keuangan gereja serta sebagai wujud pertanggungjawaban moral dan iman kepada Tuhan, sehingga untuk mendukung pelayanan gereja dalam hal pendanaan, jemaat dan para donator akan semakin yakin dan berkeralaan melakukannya. Kewajiban untuk menyusun laporan pertanggungjawaban dana gereja juga mengacu pada Undang-Undang No 14 Tahun 2008 yang merupakan Undang-Undang yang mengatur tentang Keterbukaan Informasi Publik (KIP). Dalam Undang-Undang ini disebutkan bahwa setiap badan publik yang mendapat dana/sumbangan dari masyarakat mempunyai kewajiban untuk membuka akses atas informasi publik untuk masyarakat luas. Gereja merupakan badan publik karena memperoleh dana dari publik (umat/jemaat), sehingga Gereja berkewajiban untuk menyusun laporan pertanggungjawaban dana. Permasalahan pertanggungjawaban dana gereja juga sering terjadi, contoh di gereja ini penerimaan dana khusus yang dikumpulkan jemaat untuk tujuan khusus hanya dilaporkan jumlah pemasukannya, namun dalam penggunaan tidak dilaporkan dalam bentuk laporan pertanggungjawaban kepada jemaat. Selain itu 
terdapat juga penerimaan bantuan dari pemerintah untuk pembangunan gereja yang hanya disampaikan secara lisan kepada jemaat jumlah bantuan tersebut sementara laporan penggunaan dana bantuan tersebut tidak dilaporkan secara tertulis, sementara gereja tersebut belum selesai pembangunannya seratus persen namun jumlah bantuan dana yang diberikan sudah tidak mencukupi untuk melanjutkan pembangunan sehingga pembangunan gerejapun diberhentikan. Masalah yang sering terjadi juga yaitu pemasukan dana dalam bentuk persembahan yang tidak dilaporkan sehingga ada jemaat yang harus mengkomplain kepada pengelola keuangan gereja baru dilaporkan.

Dalam pertanggungjawaban dana, gereja juga mempunyai otonomi (berdiri sendiri) yang berarti dituntut untuk mengadakan pencatatan yang terpadu yang memungkinkan adanya pertanggungjawaban bagi para pelaksana keuangannya. Tata Gereja merupakan suatu landasan berorganisasi gereja, yang meliputi beberapa hal mendasar diantaranya nama, tempat kedudukan, pengakuan iman, azas, tujuan, usaha, keanggotaan, persidangan, pengelolaan keuangan, kerjasama dan penerimaan anggota, serta perubahan dan pengesahan tata dasar. Dalam mempertanggungjawabkan dana, gereja mengacu pada tata gereja GMIM. Pada kenyataannya tata gereja tidak ditampilkan bentuk pertanggungjawaban dana yang harus dibuat, namun sesuai dengan data yang diperoleh di kantor sinode GMIM bagian keuangan, sebenarnya bentuk pertanggungjawaban dana GMIM sudah ada tapi pelaksanaannya di gereja-gereja GMIM se kota Manado belum maksimal sehingga pelaporan pertanggungjawaban dana GMIM dilaksanakan sesuai dengan kemampuan dan kemauan gereja masing-masing.

Oleh karena itu komitmen, kualitas sumber daya manusia, perangkat pendukung dan motivasi merupakan beberapa faktor yang menentukan kemampuan penyusunan laporan pertanggungjawaban dana Gereja Masehi Injili di Minahasa yang tepat bagi gereja untuk memanajemen kegiatan termasuk mengelola keuangannya. Salah satu organisasi sektor publik dalam hal ini pemerintah, ada beberapa kendala dalam mengimplementasikan sistem akuntansi sehingga berimplikasi pada ketidakhandalan dan ketidaktepatan waktu dalam menghasilkan laporan keuangan yang menurut Halim, dkk (2010) melilputi: pimpinan SKPD sering tidak memahami secara utuh tentang tugas, wewenang dan tanggungjawabnya, kapasitas SDM yang terbatas, komitmen yang tidak memadai, penguasaan tentang peraturan keuangan dan akuntansi yang rendah, keterbatasan fasilitas kerja yang terbatas atau perangkat pendukung (komputer) dan prasarana tugas serta belum berjalannya koordinasi antara unit-unit yang bertanggungjawab dalam pengelolaan keuangan. Berdasarkan fenomena dan hasil penelitian sebelumnya seperti tersebut di atas maka penulis termotivasi untuk melakukan penelitian tentang kinerja organisasi sektor publik dalam hal ini Gereja Masehi Injili di Minahasa yanga ada di Provinsi Sulawesi Utara dalam kemampuan penyusunan laporan pertanggungjawaban dana dengan judul "Analisis Faktor-faktor yang Mempengaruhi Pelaksanaan Pelaporan Pertanggungjawaban Dana pada Gereja Masehi Injili di Minahasa Kota Manado".

\subsection{Rumusan Masalah}

1. Apakah Komitmen, Sumber Daya Manusia, Perangkat pendukung dan Motivasi secara simultan berpengaruh terhadap pelaksanaan pelaporan pertanggungjawaban dana Gereja Masehi Injili di Minahasa (GMIM) kota Manado ?

2. Apakah Komitmen secara parsial berpengaruh terhadap pelaksanaan pelaporan pertanggungjawaban dana Gereja Masehi Injili di Minahasa (GMIM) kota Manado ?

3. Apakah Kualitas Sumber Daya Manusia secara parsial berpengaruh terhadap pelaksanaan pelaporan pertanggungjawaban dana Gereja Masehi Injili di Minahasa (GMIM) kota Manado ?

4. Apakah Perangkat Pendukung secara parsial berpengaruh terhadap pelaksanaan pelaporan pertanggungjawaban dana Gereja Masehi Injili di Minahasa (GMIM) kota Manado ?

5. Apakah Motivasi secara parsial berpengaruh terhadap pelaksanaan pelaporan pertanggungjawaban dana Gereja Masehi Injili di Minahasa (GMIM) kota Manado ?

\subsection{Tujuan Penelitian}

Untuk mengetahui dan menganalisis pengaruh Komitmen, Sumber Daya Manusia, Perangkat pendukung dan Motivasi berpengaruh secara simultan terhadap pelaksanaan pelaporan pertanggungjawaban dana Gereja Masehi Injili di Minahasa (GMIM) kota Manado, Untuk mengetahui dan menganalisis pengaruh Komitmen secara parsial terhadap pelaksanaan pelaporan pertanggungjawaban dana Gereja Masehi Injili di Minahasa (GMIM) kota Manado., Untuk mengetahui dan menganalisis pengaruh Kualitas Sumber Daya Manusia secara parsial terhadap pelaksanaan pelaporan pertanggungjawaban dana Gereja Masehi Injili di Minahasa (GMIM) kota Manado, Untuk mengetahui dan menganalisis pengaruh Perangkat Pendukung secara parsial terhadap pelaksanaan pelaporan pertanggungjawaban dana Gereja Masehi Injili di Minahasa (GMIM) kota 
Manado, Untuk mengetahui dan menganalisis pengaruh Motivasi secara parsial terhadap pelaksanaan pelaporan pertanggungjawaban dana Gereja Masehi Injili di Minahasa (GMIM) kota Manado.

\subsection{Manfaat Penelitian}

1. Bagi organisasi Gereja Masehi Injili di Minahasa (GMIM) baik di aras Jemaat, wilayah dan sinode, penelitian ini diharapkan dapat memberikan sumbangan pemikiran.

2. Bagi peneliti, diharapkan dapat menambah pengalaman, pemahaman kemampuan intelektual.

3. Bagi dunia pendidikan, diharapkan bermanfaat bagi perkembangan ilmu.

\subsection{Landasan Teori}

\section{BAB II LANDASAN TEORI}

\subsubsection{Teori Keagenan (Agency Theory)}

Teori ini dikemukakan oleh Michael C. Jensen dan William H. Meckling pada tahun 1976. Teori agency menurut Handono Mardiyanto (2009:263) ketidakselarasan kepentingan antara pemilik perusahaan dan kreditor. Menurut Jensen dan Meckling, agency theory adalah masalah yang berkaitan dengan perbedaan kepentingan dalam hal pengambilan keputusan antara agen dan principal. Hubungan kontraktual antara principal atau pemilik perusahaan dengan agency atau manajemen perusahaan sebagai pengelola dimana terjadi pendelegasian wewenang dari pemilik kepada pengelola, inilah yang dibahas dalam teori ini.

Laporan keuangan merupakan sarana akuntabilitas manajemen kepada pemilik. Sehingga sebagai wujud pertanggungjawaban, agen akan berusaha memenuhi keinginan principal dalam hal ini pelaporan keuangan yang transparan dan informatif akan tetapi tanpa merugikan mereka sebagai agen. Demikian juga di dalam organisasi keagamaan dalam hal ini Gereja Masehi Injili di Minahasa, BPMJ, para pendeta, penatua, syamas dan segenap kelengkapan pelayanannya baik di aras kolom, jemaat, wilayah bahkan sinode adalah agen-agen yang dipercayakan oleh jemaat untuk mengelola kegiatan pelayanan yang di dalamnya termasuk pengelolaan keuangan harus juga membuat laporan pertanggungjawab dana atas kegiatan-kegitan pelayanan yang diberikan dari pihak jemaat maupun dari pihak luar. Disinilah bisa terjadi gesekan-gesekan atau konflik karena perbedaan informasi yang dimiliki.

\subsubsection{Teori pelayanan (Stewardship Theory)}

Menurut James H. Davids, F. Favid Schoorman dan Lex Donaldson, (1997) yang dikutip oleh Yeishi Seviyane (2012:12), stewardship theory mendefinisikan situasi dimana manajemen tidaklah termotivasi oleh tujuan-tujuan individu tetapi lebih ditujukan pada sasaran hasil utama mereka untuk kepentingan organisasi. Teori tersebut mengasumsikan bahwa adanya hubungan yang kuat antara kepuasan dan kesuksesan organisasi.

Stewardship theory memandang bahwa manajemen organisasi sebagai "stewards/pelayan", akan bertindak dengan penuh kesadaran, arif dan bijaksana bagi kepentingan organisasi. Selain itu, teori ini menggunakan pendekatan governace yaitu menghasilkan informasi laporan pertanggungjawaban dana yang berkualitas.

Implikasi teori stewardship terhadap penelitian ini, dapat menjelaskan eksistensi Gereja sebagai suatu organisasi yang dapat dipercaya melaksanakan tugas dan fungsinya dengan tepat, membuat pertanggungjawaban dana yang diamanahkan jemaat kepadanya, sehingga ada damai sejahtera ketika Gereja menjalankan pelayanannya kepada Tuhan dan kepada jemaat.

\subsubsection{Laporan Pertanggungjawaban Dana Gereja Masehi Injili di Minahasa (GMIM)}

Laporan merupakan suatu bentuk pertanggungjawaban atas suatu tindakan atau kegiatan yang dilakukan. Laporan berisi informasi yang didukung oleh data yang lengkap sesuai dengan fakta yang ditemukan. Data disusun sedemikian rupa sehingga akurasi informasi yang kita berikan dapat dipercaya dan mudah dipahami (Soegito dalam Wardani 2008). Berdasarkan pendapat tersebut, dapat disimpulkan bahwa laporan adalah suatu bentuk penyampaian informasi yang didukung oleh data yang lengkap sesuai dengan fakta sehingga informasi yang diberikan dapat dipercaya serta mudah dipahami. Dalam penyampaiannya, laporan dapat bersifat lisan maupun tertulis.

Dalam pelaksanaannya, laporan pertanggungjawaban dana GMIM disusun mengacu pada Tata Gereja yang diterbitkan oleh Badan Pekerja Majelis Sinode bersama dengan Para pendeta, penatua dan syamas di jemaat masing-masing melalui sidang manjelis sinode. Dana yang dimaksud sesuai dengan Peraturan Tata Gereja Nomor 10 Bab 1 pasal 2 mengatakan bahwa adapun sumber dana GMIM antara lain:

1. Persembahan: a. semua bentuk pemberian dari setiap anggota atau rumah tangga GMIM berupa persembahan persepuluhan dan persembahan syukur lainnya; b. persembahan dalam semua ibadah yang diselenggarakan oleh dan atas nama GMIM;

2. Usaha-usaha: a. lembaga dalam lingkungan GMIM; b. hasil dari kekayaan GMIM, baik dari barang bergerak maupun tidak bergerak yang dikelola sendiri maupun yang disewakan dan dikontrakkan; $c$. 
penggalangan dana oleh yang dipercayakan Badan Pekerja Majelis dan Panitia yang dibentuk di semua aras yang tidak bertentangan dengan Tata Dasar dan peraturan perundang-undangan yang berlaku.

3. Sumbangan dan bantuan Gereja dan lembaga kristen, pemerintah maupun swasta di dalam dan di luar negeri tanpa mengikat.

4. Dana khusus: a. dana yang diperoleh atau dipupuk oleh jemaat, wilayah dan sinode untuk tujuan khusus; b. pemberian berupa hibah, wasiat dan lain-lain kepada jemaat, wilayah dan sinode; c. dana pensiun dan dana sehat pekerja GMIM; d. dana abadi.

5. Penerimaan lain-lain yang sah yang tidak mengikat dan tidak bertentangan dengan Tata Dasar dan peraturan perundang-undangan yang berlaku.

Adapun Pengelola Keuangan GMIM sesuai dengan pasal 9 tentang Pengelola Keuangan antara lain:

1. Pengelola di jemaat ialah: a. Ketua dan Bendahara Badan Pekerja Majelis Jemaat; b. semua syamas; c. Asisten Bendahara Komisi Pelayanan Kategorial Jemaat; d. panitia yang dibentuk oleh Badan Pekerja Majelis Jemaat.

2. Pengelola di wilayah ialah: a. Ketua dan Bendahara Badan Pekerja Majelis Wilayah; b. Asisten Bendahara Komisi Pelayanan Kategorial Wilayah; c. panitia yang dibentuk oleh Badan Pekerja Majelis Wilayah.

3. Pelaksana di Sinode ialah: a. Ketua dan Bendahara Badan Pekerja Majelis Sinode; b. Asisten Bendahara Komisi Pelayanan Kategorial Sinode; c. Lembaga-Lembaga dan Panitia-Panitia yang dibentuk oleh Badan Pekerja Majelis Sinode.

\subsubsection{Pelaksanaan pelaporan pertanggungjawan dana GMIM}

Sesuai dengan Tata Gereja Nomor 10 Bab III Pasal 12 tentang Laporan dan Pertanggungjawaban mengatakan bahwa Setiap bulan, Badan Pekerja Majelis Jemaat melaporkan posisi pertanggungjawaban dana jemaat kepada sidang majelis jemaat dan setiap enam bulan mempertanggungjawabkannya kepada sidang majelis jemaat. Badan Pekerja Majelis Wilayah melaporkan dan mempertanggungjawabkan dana wilayah dalam sidang majelis wilayah tiap tiga bulan dan akhir tahun anggaran melaporkannya kepada Badan Pekerja Majelis Sinode dengan tembusan kepada badan pengawas dan kepada semua Badan Pekerja Majelis Jemaat dalam wilayah yang bersangkutan. Pimpinan lembaga-lembaga aras Sinode melaporkan dan mempertanggungjawabkan dana masing-masing kepada Badan Pekerja Majelis Sinode setiap tiga bulan dan setiap akhir tahun. Komisi Pelayanan Kategorial dan Komisi Kerja di semua aras melaporkan dana masingmasing kepada badan pekerja majelis di semua aras setiap bulan dan setiap akhir tahun. Badan Pekerja Majelis Sinode melaporkan seluruh perbendaharan sinode kepada jemaat melalui wilayah tiap tahun dan kepada sidang majelis sinode setiap tahun. Dan untuk Dana khusus yang diperoleh dari jemaat wajib di laporkan Badan Pekerja Majelis jemaat kepada jemaat yang Gereja. Untuk dana hasil sumbangan dari donator dalam rangka kegiatan pelayanan gereja, Panitia yang dibentuk di semua aras melaporkan dan mempertanggungjawabkan kegiatan dan per-bendaharaan kepada badan pekerja majelis di semua aras selambat-lambatnya satu bulan setelah pelaksanaan kegiatan dan mempublikasikan kepada jemaat. Setiap minggunya, Badan Pekerja Majelis Jemaat harus menyajikan Laporan pertanggungjawaban dana Gereja yang dicantumkan dalam Warta Jemaat.

\subsection{Penelitian Terdahulu}

Penelitian Azhar (2007) tentang Faktor-Faktor Yang Mempengauhi Keberhasilan Penerapan Permendagri Nomor 13 Tahun 2006 pada pemerintah Kota Banda Aceh. Hasil penelitian yang didapatkan pada pemerintah kota Banda Aceh menyimpulkan bahwa secara parsial Variabel Komitmen, SDM dan perangkat pendukung berengaruh terhadap keberhasilan penerapan permendagri 13 Tahun 2006 sedangkan variable regulasi tidak berpengaruh.

Penelitian Sulani (2009) tentang faktor-faktor yang mendukung Keberhasilan Penerapan PP 24 tahun 2005 Kabupaten Labuhan Batu. Hasil penelitian menyimpulkan bahwa secara parsial variable komitmen berpengaruh terhadap keberhasilan penerapan PP 24 tahun 2005 di Kabupaten Labuhan Batu sedangkan vaiabel Sumber Daya Manusia dan Perangkat Pendukung tidak berpengaruh. 
3.1 Kerangka Konseptual Penelitian

Bab III Kerangka Konseptual

Gambar 3.1 Kerangka Konseptual

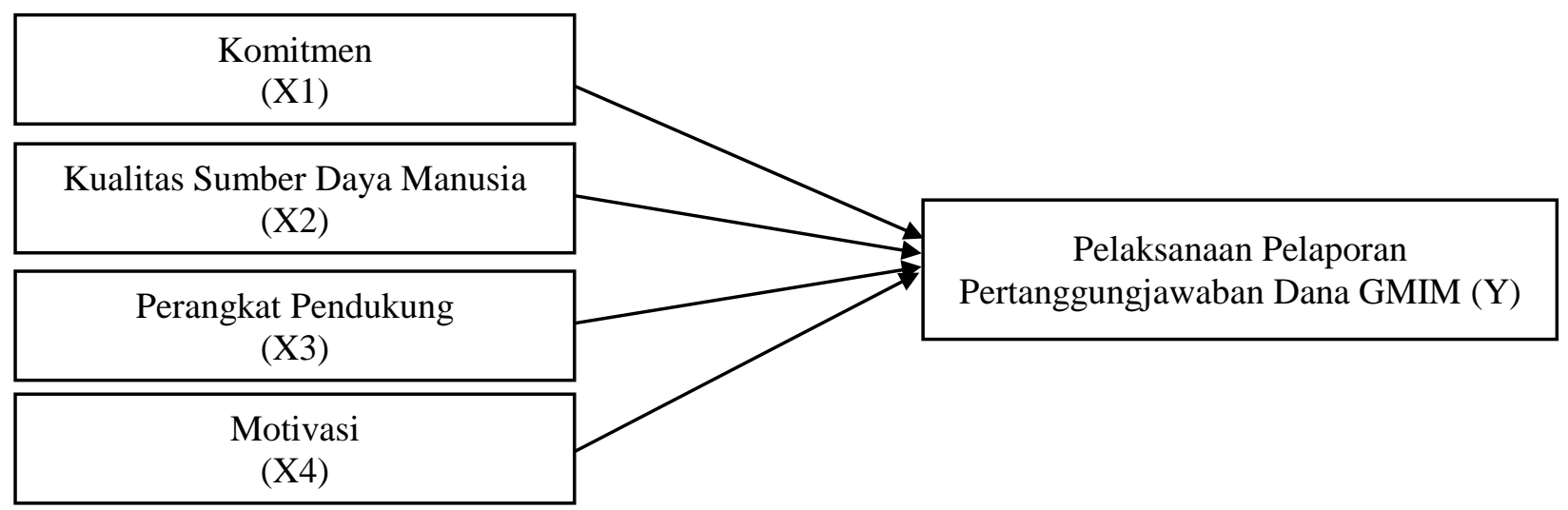

\subsection{Hipotesis}

1. Pengaruh secara simultan variable komitmen, kualitas sumber daya manusia, perangkat pendukung dan motivasi terhadap pelaksanaan pelaporan pertanggungjawaban dana Gereja.

Warisno (2008) dalam penelitiannya menyimpulkan bahwa kualitas sumber daya manusia, motivasi, komunikasi, sarana pendukung dan komitmen organisasi secara simultan berpengaruh terhadap kinerja. Pemahaman sistem akuntansi dan pengelola keuangan berpengaruh terhadap kinerja SKPD baik secara simultan maupun parsial (Tuasikal, 2008).

$\mathrm{H}_{1} \quad$ : Komitmen, kualitas sumber daya manusia, perangkat pendukung dan motivasi berpengaruh secara simultan terhadap pelaksanaan pelaporan pertanggungjawaban dana Gereja Masehi Injili di Minahasa.

2. Pengaruh variable komitmen terhadap pelaksanaan pelaporan pertanggungjawaban dana Gereja.

Variable komitmen berpengaruh terhadap kemampuan pegawai terkait dalam menyusun laporan pertanggungjawaban dana Gereja. Menurut Halim, dkk (2010), bahwa pentingnya komitmen pejabat pengelola keuangan daerah untuk penyelenggaraan akuntansi dan pelaporan keuangan untuk menghasilkan laporan keuangan yang handal dan tepat waktu.

Penelitian Azhar (2007) bahwa komitmen berpengaruh terhadap penerapan permendagri 13 tahun 2006 karena semakin tinggi komitmen dari anggota organisasi maka semakin berhasil dalam penerapan Permendagri 13 tahun 2006 demikian juga dalam hal penyusunan laporan keuangan pemerintah daerah.

$\mathrm{H}_{2}$ : Komitmen berpengaruh terhadap kemampuan penyusunan laporan pertanggungjawaban dana Gereja Masehi Injili di Minahasa.

3. Pengaruh variable kualitas sumber daya manusia terhadap pelaksanaan pelaporan pertanggungjawaban dana Gereja Masehi Injili di Minahasa.

Variable kualitas sumber daya manusia bepengaruh terhadap kemampuan pegawai terkait dalam menyusun laporan petanggungjawaban dana GMIM. Menurut Halim, dkk (2010), kualitas dan kinerja organisasi sangat ditentukan oleh faktor sumber daya manusia, karena keberadaan manusia dalam suatu organisasi tidak dapat digantikan oleh unsur lainnya. Organisasi dapat mencapai sukses apabila dikelola dengan baik, karena itu diperlukan suatu manajemen sumber daya manusia yang efektif.

Penelitian Azhar (2007) bahwa sumber daya manusia berpengaruh terhadap keberhasilan penerapan pemendagri 13 tahun 2006 karena sumber daya manusia merupakan elemen organisasi yang sangat penting dan harus dikelola sebaik mungkin agar mampu memberikan kontribusi secara optimal dalam upaya pencapaian tujuan organisasi. Varibel kualitas sumber daya manusia ini juga diukur dengan kemampuan dari para penglola keuangan gereja dalam memahami peraturan tata gereja sebagai acuan penyusunan laporan pertanggungjawaban dana GMIM. Penelitian Mahardika (2011) mengatakan bahwa peraturan berpengaruh terhadap penyusunan laporan keuangan SKPD 
karena dengan mentaati peraturan yang telah ditetapkan sebagai acuan dalam penyusunan laporan keuangan maka SKPD akan melaporkan laporan keuangan tepat waktu.

$\mathrm{H}_{3} \quad$ : Kualitas sumber daya manusia berpengaruh terhadap pelaksanaan pelaporan pertanggungjawaban dana Gereja Masehi Injili di Minahasa.

4. Pengaruh variable perangkat pendukung terhadap pelaksanaan pelaporan keuangan dana GMIM.

Variable perangkat pendukung terhadap pelaksanaan pelaporan keuangan dana. Menurut Halim (2007), perangkat pendukung komputer yang digunakan untuk menjalankan sistem akutansi dalam meningkatkan efisiensi di dalam pemrosesan data transaksi sehari - hari sehingga memudahkan dalam penyajian laporan keuangan tepat waktu.

Penelitian Aidil (2010), perangkat pendukung berpengaruh terhadap penyusunan laporan keuangan. Pemerintah dengan bantuan alat untuk mendukung terlaksananya kegiatan atau pekerjaan seperti adanya perangkat keras komputer dan perangkat lunak sehingga dalam pelaksanaan pekerjaan lebih efisien dan lebih tepat waktu dalam penyajian laporan keuangan pemerintah daerah.

$\mathrm{H}_{4}$ : Perangkat pendukung berpengaruh terhadap pelaksanaan pelaporan pertanggungjawaban dana Gereja Masehi Injili di Minahasa.

5. Pengaruh variable motivasi terhadap pelaksanaan pelaporan keuangan dana GMIM.

Menurut Mathis dan Jackson (2006) pengertian Motivasi adalah hasrat di dalam seseorang menyebabkan orang tersebut melakukan tindakan. Dalam organisasi gereja, para pendeta, penatua, syamas serta pegawai gereja merupakan pelayan yang telah dipercayakan oleh Tuhan dan memberi diri untuk dipakai sesuai dengan tugas dan panggilan mereka. Biasanya dalam menjalankan tanggungjawabnya para pelayan menjalankannya tanpa mengharapkan imbalan dan meyakini bahwa melayani Tuhan merupakan tugas mulia. Terkait dengan penelitian ini, motivasi dari para pengelola keuangan gereja diukur dari seberapa besar keinginan mereka untuk menyusun laporan pertanggungjawaban dana gereja yang berkualitas dan dapat dipertaggungjawabkan dengan motivasi untuk melayani Tuhan dan jemaat.

$\mathrm{H}_{4} \quad$ : Motivasi berpengaruh terhadap pelaksanaan pelaporan pertanggungjawaban dana Gereja Masehi Injili di Minahasa.

\subsection{Model Analisis}

Model analisis yang digunakan dalam penelitian ini yaitu analisis regresi linear berganda. Menurut Sugiyono (2011), analisis regresi linier berganda digunakan oleh peneliti bila peneliti bermaksud meramalkan bagaimana keadaan (naik turunya) variabel dependen bila dua atau lebih variabel independen sebagai faktor prediktor dimanipulasi (dinaik turunkan nilainya) dengan menggunakan formula sebagai berikut:

$$
\mathbf{Y}=\alpha+\beta_{1} \mathbf{X}_{1}+\beta_{2} X_{2}+\beta_{3} X_{3}+\beta_{4} X_{4}+\varepsilon
$$

Dimana:

Y : Penyusunan laporan pertanggungjawaban dana GMIM

$\alpha \quad$ : konstanta

$\beta_{1,} \beta_{2}, \beta_{3}, \beta_{4} \quad$ : koefisien regresi

$\mathrm{X}_{1} \quad$ : Pemahaman peraturan

$\mathrm{X}_{2} \quad$ : komitmen

$\mathrm{X}_{3} \quad$ : kualitas sumber daya manusia

$\mathrm{X}_{4} \quad$ : Perangkat pendukung

$\varepsilon \quad:$ Error

\section{Bab IV \\ METODE PENELITIAN}

\subsection{Jenis/ Rancangan Penelitian}

4.1.1 Jenis Data

Jenis data yang digunakan dalam peneitian ini adalah kuantitatif.

4.1.2 Sumber Data 
Berdasarkan sumber data yang terbagi dua yaitu data primer dan data sekunder. Data primer yaitu data yang diperoleh langsung dari objek penelitian berupa kuisioner yang diberikan kepada responden pada seluruh kantor jemaat Gereja Masehi Injili di Minahasa (GMIM) disertai dengan wawancara kepada responden yang bersedia untuk mengkonfirmasi kembali kuisioner yang telah diisi, sedangkan data sekunder yaitu berupa literatur - literatur kepustakaan.

\subsection{Populasi dan Sampel Penelitian \\ 4.2.1 Populasi}

Populasi adalah wilayah generalisasi yang terdiri atas objek dan subyek yang mempunyai kuantitas dan karakteristik tertentu yang diterapkan oleh peneliti untuk dipelajari dan kemudian ditarik kesimpulan (Sugiyono, 2011). Populasi dalam penelitian ini adalah seluruh pegawai Gereja Masehi Injili di Minahasa (GMIM) di bidang keuangan dan administrasi yang ada di Kota Manado.

\subsubsection{Sampel}

Sampel adalah sebagian dari jumlah dan karakteristik yang dimiliki oleh populasi tersebut (Sugiyono, 2011). Teknik pengambilan sampel menggunakan purposive sampling pegawai kantor jemaat Gereja Masehi Injili di Minahasa. Hair et al. (1998) dikutip dari Jatmiko (2006) menyatakan bahwa jumlah sampel minimal yang harus diambil apabila menggunakan teknik analisis regresi linear berganda adalah 15 sampai 20 kali jumlah variable yang digunakan. Jumlah variable yang digunakan dalam penelitian ini adalah 4 variabel sehingga jumlah sampel minimal yang harus diambil adalah 4 X $15=60$.

\subsection{Definisi Operasional dan Pengukuran Variabel}

Penelitian ini akan menggunakan empat variable independen (Komitmen, Kualitas Sumber Daya Manusia, Perangkat Pendukung dan Motivasi) dan satu variable dependen yaitu Pelaksanaan Pelaporan Pertanggungjawaban Dana Gereja Masehi Injili di Minahasa yang tertuang dalam bentuk kuisioner hasil modifikasi penulis berdasarkan kuisioner penelitian sebelumnya oleh Terry (2013). Setiap pernyataan ini diukur dengan skala Likert 1-5 untuk setiap bobot pernyataan yaitu: Sangat Tidak Setuju (STS) Skor 1, Tidak Setuju (TS) Skor 2, Kurang Setuju (KS) Skor 3, Setuju (S) Skor 4, Sangat Setuju (SS) Skor 5.

\subsubsection{Variabel Dependen}

Pelaksanaan pelaporan Pertanggungjawaban Dana GMIM ditentukan sebagai kemampuan dari pegawai Gereja Masehi Injili di Minahasa dalam menyusun laporan pertanggungjawaban Dana Gereja, dengan menggunakan kuisioner yang terdiri dari 6 pernyataan antara lain (1). Gereja harus menyusun Rekapitulasi pengeluaran dana, (2). Gereja harus menyusun Rekapitulasi penerimaan dana, (3). Gereja harus memiliki dokumentasi bukti pengeluaran dana, (4). Gereja harus memiliki dokumentasi bukti penerimaan dana, (5). Gereja harus menyusun dan melaporkan laporan pertanggungjawaban dana tepat waktu, (6). Gereja menyusun laporan pertanggungjawaban dana dengan menggunakan jasa konsultan.

\subsubsection{Variabel Independen}

Variable independen dalam penelitian ini yaitu:

1. Komitmen

Variabel ini diukur dengan persepsi dari pegawai pengelola keuangan Gereja tentang keinginan dan sikap dalam melakukan perubahan untuk mempelajari, memahami dan menyelesaikan Laporan Pertanggungjawaban dana Gereja dengan menggunakan kuisioner yang terdiri dari 6 pertanyaan antara lain (1). Pengelola keuangan mengikuti pelantikan sebagai bentuk kesediaan untuk menjalankan tugas, (2). Diperlukan kesungguhan dalam menjalankan tugas karena telah mengucapkan janji kepada Tuhan dan Jemaat lewat pelantikan, (3). Pengelola keuangan Gereja harus siap untuk melakukan perubahan dalam proses penyusunan laporan keuangan sesuai Tata Gereja GMIM yang berlaku, (4). Menyelesaikan dan melaporkan laporan pertanggungjawaban tepat waktu, (5). Diperlukan kesungguhan dalam bekerja serta memahami perubahan peraturan, (6). Berusaha melakukan yang terbaik agar tercipta pengelolaan keuangan Gereja yang baik dan benar.

2. Kualitas Sumber Daya Manusia

Variabel ini diukur berdasarkan latar belakang pendidikan, kompetensi, pendidikan dan pelatihan yang diperoleh pegawai dengan menggunakan kuisioner yang terdiri dari 6 pertanyaan antara lain (1). Penempatan pegawai di gereja sesuai dengan latar belakang pendidikan, (2). Pengelola keuangan Gereja harus memahami Tata Gereja GMIM, (3). Pengelola keuangan Gereja harus memiliki pengalaman di bidang pengelolaan keuangan, (4). Diperlukan adanya pendidikan dan pelatihan tentang pengelolaan keuangan Gereja sehingga dapat meningkatkan keahlian, pengetahuan dan 
ketrampilan, (5). Berusaha meningkatkan kemampuan penggunaan perangkat komputer, (6). Gereja harus memiliki SDM yang mampu menyusun laporan pertanggungjawaban dana.

3. Perangkat pendukung

Variable ini diukur berdasarkan ketersediaan komputer, aplikasi software dan tenaga operator dengan menggunakan kuisioner yang terdiri dari 6 pertanyaan antara lain (1). Tersedianya perangkat komputer yang memadai secara infrastruktur, (2). Gereja menggunakan aplikasi software dalam penyusunan laporan, (3). Perangkat pendukung sangat membantu dalam penyusunan laporan tepat waktu, (4). Gereja memiliki tenaga operator Komputer yang berkualifikasi, (5). Masalah teknis terkait sistem komputerisasi dapat diatasi, (6). Gereja memiliki dan menggunakan jaringan internet yang mendukung pelaporan keuangan.

4. Motivasi

Variabel ini diukur dengan penggunaan Tata Gereja Masehi Injili di Minahasa yang terdiri dari 6 pertanyaan antara lain (1). Pengelola keuangan menjalankan tugas sebagai bentuk pelayanan kepada Tuhan dan jemaat, (2). Ada sukacita dan damai sejahtera ketika menjalankan tugas di bidang pelayanan kepada Tuhan, (3). Menjalankan tugas untuk menghasilkan laporan pertanggungjawaban gereja yang berkualitas, (4). Terciptanya kesejahteraan jemaat ketika dana gereja terkelola dengan baik, (5). Meningkatnya tingkat kepercayaan jemaat serta para donatur ketika dana gereja terkelola dengan baik, (6). Menjalankan tugas untuk hormat dan kemuliaan nama Tuhan.

\section{BAB V \\ ANALISIS DAN PEMBAHASAN HASIL PENELITIAN}

\subsection{Gambaran Umum Objek Penelitian}

Gereja Masehi Injili di Minahasa disingkat GMIM adalah persekutuan orang-orang di tanah Minahasa yang percaya kepada Yesus Kristus untuk memberitakan perbuatan-perbuatan besar Tuhan Allah danmenjadi bekat bagi orang banyak di mana pun dan kapan pun. Secara estimologis, kata "Masehi" berasal dari kata Al Maseh atau Kristus. Kata "Injil" bersumber dari bahasa Yunani Euanggelion yang berarti kabar baik. Kata "di" menerangkan bahwa GMIM secara kelembagaan hanya ada di tanah Minahasa, yang memiliki karakteristik esa, kudus, ama, rasuli dan universal.

TEMA DGD : Allah Kehidupan, Tuntunlah Kami ke dalam Keadilan dan Perdamaian

TEMA PGI \& GMIM : "Tuhan Mengangkat Kita Dari Samudera Raya” (Bdk Mzm 71 : 20 b)

SUB TEMA : "Dalam Solidaritas Dengan Sesama Anak Bangsa Kita Tetap Mengamalkan Nilai-nilai Pancasila Guna Menanggulangi Kemiskinan, Ketidakadilan, Radikalisme, dan Perusakan Lingkungan”

Organisasi Gereja Masehi Injili di Minahasa (GMIM) terbagi 110 wilayah di Sulawesi Utara dan terdiri dari 933 jemaat. Sedangkan wilayah pelayanan di kota Manado berjumlah 22 wilayah yang terbagi atas 160 jemaat. Objek penelitian dalam penelitian ini adalah pegawai gereja di bidang keuangan baik yang ada di gereja GMIM di kota Manado dan yang ada di kantor Sinode. Menurut hasil wawancara penulis kepada anggota jemaat beberapa gereja tertentu bahwa di gereja mereka tidak memiliki pegawai sehingga untuk kegiatan pelayanan dan pengelolaan keuangan langsung ditangani oleh bendahara bersama dengan pendeta jemaat. Tabel 5.1 menunjukan sebaran populasi dan sampel penelitian ini.

Tabel 5.2. Data Demografi Responden

\begin{tabular}{|c|c|c|c|}
\hline Data Deskripsi & Keterangan & Jumlah & Presentase \\
\hline \multirow{2}{*}{ Jenis Kelamin } & Laki-laki & 18 & $32 \%$ \\
\hline & Perempuan & 42 & $68 \%$ \\
\hline \multirow{4}{*}{ Usia } & $20-25$ tahun & 8 & $13 \%$ \\
\hline & 26-30 tahun & 10 & $17 \%$ \\
\hline & $31-40$ tahun & 27 & $45 \%$ \\
\hline & Di atas 40 tahun & 15 & $25 \%$ \\
\hline \multirow{7}{*}{ Tingkat Pendidikan } & SD & 3 & $5 \%$ \\
\hline & SMP & 4 & $7 \%$ \\
\hline & SMA/SMU/SMK & 45 & $75 \%$ \\
\hline & D-III & - & - \\
\hline & S1 & 8 & $13 \%$ \\
\hline & $\mathrm{S} 2$ & - & - \\
\hline & S3 & - & - \\
\hline \multirow{4}{*}{$\begin{array}{c}\text { Masa jabatan Pegawai Bidang } \\
\text { Administrasi/ Keuangan }\end{array}$} & $1-5$ tahun & 7 & $12 \%$ \\
\hline & 6-10 tahun & 23 & $38 \%$ \\
\hline & 11-15 tahun & 19 & $32 \%$ \\
\hline & Di atas 15 tahun & 11 & $18 \%$ \\
\hline
\end{tabular}

Sumber : Data diolah, 2015 


\subsection{Hasil Penelitian dan Pembahasan}

\subsubsection{Statistik Deskriptif}

Pada tabel 5.2 berikut dapat dilihat hasil ringkasan analisis statistik deskriptif variabel-variabel yang digunakan dalam penelitian ini.

Tabel 5.2. Statistik Deskriptif Variabel Penelitian Descriptive Statistics

\begin{tabular}{|c|c|c|c|c|c|}
\hline & $\mathrm{N}$ & Minimum & Maximum & Mean & Std. Deviation \\
\hline $\mathrm{X} 1.1$ & 60 & 3.00 & 5.00 & 4.4500 & .53441 \\
\hline $\mathrm{X} 1.2$ & 60 & 4.00 & 5.00 & 4.3000 & .46212 \\
\hline $\mathrm{X} 1.3$ & 60 & 4.00 & 5.00 & 4.4167 & .49717 \\
\hline$X 1.4$ & 60 & 3.00 & 5.00 & 4.4000 & .52722 \\
\hline$X 1.5$ & 60 & 4.00 & 5.00 & 4.3333 & .47538 \\
\hline X1.6 & 60 & 4.00 & 5.00 & 4.7333 & .44595 \\
\hline X1.TOTAL & 60 & 23.00 & 30.00 & 26.6333 & 2.38617 \\
\hline X2.1 & 60 & 2.00 & 5.00 & 3.9167 & .96184 \\
\hline$X 2.2$ & 60 & 4.00 & 5.00 & 4.5667 & .49972 \\
\hline$X 2.3$ & 60 & 3.00 & 5.00 & 4.4333 & .56348 \\
\hline X2.4 & 60 & 4.00 & 5.00 & 4.5333 & .50310 \\
\hline X2.5 & 60 & 4.00 & 5.00 & 4.4167 & .49717 \\
\hline X2.6 & 60 & 4.00 & 5.00 & 4.5500 & .50169 \\
\hline X2.TOTAL & 60 & 22.00 & 30.00 & 26.4167 & 2.76351 \\
\hline X3.1 & 60 & 4.00 & 5.00 & 4.5167 & .50394 \\
\hline X3.2 & 60 & 3.00 & 5.00 & 4.3000 & .59089 \\
\hline X3.3 & 60 & 3.00 & 5.00 & 4.5333 & .53573 \\
\hline X3.4 & 60 & 3.00 & 5.00 & 4.4333 & .64746 \\
\hline X3.5 & 60 & 3.00 & 5.00 & 4.3333 & .54202 \\
\hline X3.6 & 60 & 3.00 & 5.00 & 4.3167 & .77002 \\
\hline X3.TOTAL & 60 & 21.00 & 30.00 & 26.4333 & 2.65130 \\
\hline$\times 4.1$ & 60 & 4.00 & 5.00 & 4.5167 & .50394 \\
\hline$X 4.2$ & 60 & 4.00 & 5.00 & 4.6167 & .49030 \\
\hline$X 4.3$ & 60 & 4.00 & 5.00 & 4.5333 & .50310 \\
\hline$X 4.4$ & 60 & 4.00 & 5.00 & 4.5167 & .50394 \\
\hline X4.5 & 60 & 4.00 & 5.00 & 4.4667 & .50310 \\
\hline $\mathrm{X} 4.6$ & 60 & 4.00 & 5.00 & 4.7333 & .44595 \\
\hline X4.TOTAL & 60 & 24.00 & 30.00 & 27.3833 & 2.17140 \\
\hline Y.1 & 60 & 4.00 & 5.00 & 4.7167 & .45442 \\
\hline Y.2 & 60 & 4.00 & 5.00 & 4.7167 & .45442 \\
\hline Y.3 & 60 & 4.00 & 5.00 & 4.7833 & .41545 \\
\hline Y.4 & 60 & 4.00 & 5.00 & 4.8000 & .40338 \\
\hline Y.5 & 60 & 3.00 & 5.00 & 4.5667 & .53256 \\
\hline Y.6 & 60 & 1.00 & 5.00 & 3.0333 & .68807 \\
\hline Y.TOTAL & 60 & 21.00 & 30.00 & 26.6167 & 1.94929 \\
\hline Valid N (listwise) & 60 & & & & \\
\hline
\end{tabular}

Sumber: Data diolah, 2015

Berdasarkan hasil statistik deskriptif di atas dapat dilihat bahwa variabel Komitmen $\left(\mathrm{X}_{1}\right)$ nilai ratarata (mean) sebesar 4,4 responden menjawab setuju bahwa komitmen berpengaruh terhadap pelaksanaan pelaporan pertanggungjawaban dana GMIM. Sementara nilai minimum variabel komitmen sebesar 3 yang menunjukan bahwa paling sedikit responden menjawab kurang setuju bahwa komitmen berpengaruh terhadap pelaksanaan pelaporan pertanggungjawaban dana GMM. Nilai maximum dari variabel komitmen sebesar 5 yang menunjukan bahwa paling banyak responden menjawab sangat setuju bahwa komitmen berpengaruh terhadap pelaksanaan pelaporan pertanggungjawaban dana GMIM.

Variabel Kualitas Sumber Daya Manusia $\left(\mathrm{X}_{2}\right)$ dengan nilai rata-rata (mean) sebesar 4,4 responden menjawab setuju bahwa kualitas sumber daya manusia berpengaruh terhadap pelaksanaan pelaporan pertanggungjawaban dana GMIM. Sementara nilai minimum variabel kualitas sumber daya manusia sebesar 2 yang menunjukan bahwa paling sedikit responden menjawab tidak setuju bahwa kualitas sumber daya 
manusia berpengaruh terhadap pelaksanaan pelaporan pertanggungjawaban dana GMIM. Nilai maximum dari variabel kualitas sumber daya manusia sebesar 5 yang menunjukan bahwa paling banyak responden menjawab sangat setuju bahwa kualitas sumber daya manusia berpengaruh terhadap pelaksanaan pelaporan pertanggungjawaban dana GMIM.

Variabel Perangkat Pendukung $\left(\mathrm{X}_{3}\right)$ dengan nilai rata-rata (mean) sebesar 4,4 responden menjawab setuju bahwa Perangkat Pendukung berpengaruh terhadap pelaksanaan pelaporan pertanggungjawaban dana GMIM. Sementara nilai minimum variabel Perangkat Pendukung sebesar 3 yang menunjukan bahwa paling sedikit responden menjawab kurang setuju bahwa Perangkat Pendukung berpengaruh terhadap pelaksanaan pelaporan pertanggungjawaban dana GMIM. Nilai maximum dari variabel kualitas sumber daya manusia sebesar 5 yang menunjukan bahwa paling banyak responden menjawab sangat setuju bahwa Perangkat Pendukung berpengaruh terhadap pelaksanaan pelaporan pertanggungjawaban dana GMIM.

Variabel motivasi $\left(\mathrm{X}_{4}\right)$ dengan nilai rata-rata (mean) sebesar 4,5 responden menjawab setuju bahwa motivasi berpengaruh terhadap pelaksanaan pelaporan pertanggungjawaban dana GMIM. Sementara nilai minimum variabel motivasi sebesar 3 yang menunjukan bahwa paling sedikit responden menjawab kurang setuju bahwa motivasi berpengaruh terhadap pelaksanaan pelaporan pertanggungjawaban dana GMIM. Nilai maximum dari variabel motivasi sebesar 5 yang menunjukan bahwa paling banyak responden menjawab sangat setuju bahwa motivasi berpengaruh terhadap pelaksanaan pelaporan pertanggungjawaban dana GMIM.

\subsubsection{Uji Reliabilitas dan Validitas Kuisioner}

\subsubsection{Uji Reliabilitas}

Hasil uji reliabilitas variabel Y (Pelaksanaan Pelaporan Pertanggungjawaban Dana GMIM) pada table 5.3 menunjukan bahwa nilai Cronbach Alpha variabel Y adalah sebesar 0,73 lebih besar dari 0,60. Hal tersebut menjelaskan bahwa jawaban terhadap pertanyaan dalam kuisioner terkait dengan variabel $\mathrm{Y}$ (Pelaksanaan Pelaporan Pertanggungjawaban Dana GMIM) adalah handal atau reliabel.

Hasil uji reliabilitas variabel $\mathrm{X}_{1}$ (Komitmen) pada table 5.4 menunjukan bahwa nilai Cronbach Alpha variabel $\mathrm{X}_{1}$ adalah sebesar 0,89 lebih besar dari 0,60. Hal tersebut menjelaskan bahwa jawaban terhadap pertanyaan dalam kuisioner terkait dengan variabel $\mathrm{X}_{1}$ (Komitmen) adalah handal atau reliabel.

Hasil uji reliabilitas variabel $\mathrm{X}_{2}$ (Kualitas Sumber Daya Manusia) pada table 5.5 menunjukan bahwa nilai Cronbach Alpha variabel $\mathrm{X}_{2}$ adalah sebesar 0,85 lebih besar dari 0,60. Hal tersebut menjelaskan bahwa jawaban terhadap pertanyaan dalam kuisioner terkait dengan variabel $\mathrm{X}_{2}$ (Kualitas Sumber Daya Manusia) adalah handal atau reliabel.

Hasil uji reliabilitas variabel $\mathrm{X}_{3}$ (Perangkat Pendukung) pada table 5.6 menunjukan bahwa nilai Cronbach Alpha variabel $\mathrm{X}_{3}$ adalah sebesar 0,82 lebih besar dari 0,60. Hal tersebut menjelaskan bahwa jawaban terhadap pertanyaan dalam kuisioner terkait dengan variabel $X_{3}$ (Perangkat Pendukung) adalah handal atau reliabel.

Hasil uji reliabilitas variabel $\mathrm{X}_{4}$ (Motivasi) pada table 5.7 menunjukan bahwa nilai Cronbach Alpha variabel $\mathrm{X}_{4}$ adalah sebesar 0,83 lebih besar dari 0,60. Hal tersebut menjelaskan bahwa jawaban terhadap pertanyaan dalam kuisioner terkait dengan variabel $\mathrm{X}_{4}$ (Motivasi) adalah handal atau reliabel.

\subsubsection{Uji Validitas}

Hasil uji validitas Y (Pelaksanaan Pelaporan Pertanggungjawaban Dana GMIM) pada tabel 5.8 dalam tampilan output SPSS terlihat bahwa korelasi antar masing-masing indikator $\left(\mathrm{Y}_{1}-\mathrm{Y}_{6}\right)$ terhadap total skor kontruk (Y) yaitu 0.794, 0.794, 0.775, 0.763, 0.605, 0.401 menunjukan hasil yang signifikan.

Hasil uji validitas $X_{1}$ (Komitmen) pada tabel 5.9 dalam tampilan output SPSS terlihat bahwa korelasi antar masing-masing indikator $\left(\mathrm{X}_{1.1}-\mathrm{X}_{1.6}\right)$ terhadap total skor kontruk $\left(\mathrm{X}_{1}\right)$ yakni $0.823,0.808,0.888,0.873$, 0.782, 0.671 menunjukan hasil yang signifikan.

Hasil uji validitas $\mathrm{X}_{2}$ (Kualitas Sumber Daya Manusia) pada tabel 5.10 dalam tampilan output SPSS terlihat bahwa korelasi antar masing-masing indikator $\left(\mathrm{X}_{2.1}-\mathrm{X}_{2.6}\right)$ terhadap total skor kontruk $\left(\mathrm{X}_{2}\right)$ yakni $0.747,0.796,0.818,0.703,0.821,0.847$ menunjukan hasil yang signifikan.

Hasil uji validitas $X_{3}$ (Perangkat Pendukung) pada tabel 5.11 dalam tampilan output SPSS terlihat bahwa korelasi antar masing-masing indikator $\left(X_{3.1}-X_{3.6}\right)$ terhadap total skor kontruk $\left(X_{3}\right)$ yakni 0.730 , $0.824,0.598,0.837,0.818,0.637$ menunjukan hasil yang signifikan.

Hasil uji validitas $\mathrm{X}_{4}$ (Motivasi) pada tabel 5.12 dalam tampilan output SPSS terlihat bahwa korelasi antar masing-masing indikator $\left(\mathrm{X}_{4.1}-\mathrm{X}_{4.6}\right)$ terhadap total skor kontruk $\left(\mathrm{X}_{4}\right)$ yakni $0.776,0.713,0.787,0.683$, $0.702,0.755$ menunjukan hasil yang signifikan. 


\subsubsection{Uji Asumsi Klasik \\ 5.3.2.1 Uji Normalitas}

Berdasarkan hasil Uji Kolmogorov Smirnov pada tabel 5.13 menunjukan bahwa nilai Kolmogorov smirnov seluruh variabel dalam penelitian ini adalah sebesar 0,20 yang lebih besar atau berada di atas tingkat signifikansi statistik yakni 0,05 , sehingga dapat disimpulkan bahwa data dalam penelitian ini terdistribusi normal. Hal ini menunjukan bahwa data dalam penelitian ini lolos uji asumsi klasik, yakni uji normalitas data.

\subsubsection{Uji Autokorelasi}

Berdasarkan hasil Uji Autokorelasi dengan melihat angka Durbin Watson pada tabel 5.14 menunjukan bahwa angka Durbin Watson (DW) sebesar 2,078. Apabila tingkat signifikasi $\alpha=0,05$ dan $\mathrm{n}=$ 60 dan $\mathrm{k}=4$ maka nilai $\mathrm{dU}=1,7274 ; \mathrm{dL}=1,4797$. Pengujian untuk uji autokorealasi penelitian ini menunjukan hasil bahwa persamaan model 1 memenuhi syarat asumsi klasik autokorelasi $\mathrm{dU}<\mathrm{DW}<4$-dL $(1,7274<2,078<(4-1,4797=2,5206)$. Hal ini menunjukan bahwa data dalam penelitian ini lolos uji asumsi klasik, yakni uji autokorelasi.

\subsubsection{Uji Heterokedastisitas}

Berdasarkan hasil uji heterokedastisitas pada tabel 5.15 menunjukan bahwa setiap variabel independen memiliki tingkat signifikan di atas 0.05 atas nilai residualnya, sehingga dapat disimpulkan bahwa varians data penelitian tidak mengalami efek heteroskedastisitas atau varians data adalah homoskedastisitas. Hal ini menunjukan bahwa data dalam penelitian ini lolos uji asumsi klasik, yakni uji heteroskedastisitas.

\subsubsection{Uji Multikolinearitas}

Berdasarkan tabel 5.16 dalam Collinearity Statistic menunjukan bahwa nilai VIF setiap variabel independen yakni $\mathrm{X}_{1}-\mathrm{X}_{4}$ masing-masing antara lain 1.340, 1.748, 1.458, 1.079 adalah berada di bawah 10, maka dapat disimpulkan bahwa antar variabel independen tidak terjadi efek multikolinearitas. Hal ini menunjukan bahwa data dalam penelitian ini lolos dari uji asumsi klasik yaitu tidak terdapat multikolinearitas dalam data penelitian sehingga data ini dinilai layak untuk pengujian selanjutnya.

\subsubsection{Pengujian Hipotesis Penelitian}

\subsubsection{Koefisien Determinasi}

Berdasarkan tabel 5.17 menunjukan bahwa nilai koefisien determinasi yakni $\mathrm{R}$ Square $\left(\mathrm{R}^{2}\right)$ vaiabel $\mathrm{X}_{1}$ (Komiten), $\mathrm{X}_{2}$ (Kualitas Sumber Daya Manusia), $\mathrm{X}_{3}$ (Perangkat Pendukung), $\mathrm{X}_{4}$ (Motivasi) adalah sebesar 0,230 atau 23\%. Hal ini menunjukan bahwa besarnya pengaruh variabel bebas, yaitu Komitmen, Kualitas Sumber Daya Manusia, Perangkat Pendukung dan Motivasi terhadap variabel terikat yaitu Pelaksanaan Pelaporan Pertanggungjawaban Dana GMIM yang diterangkan oleh model persamaan dalam penelitian ini adalah sebesar $23 \%$, sedangkan sisanya diterangkan oleh faktor-faktor lain yang tidak dimasukan dalam model regresi.

\subsubsection{Uji F}

Berdasarkan tabel 5.18 hasil uji $\mathrm{F}$ dengan menggunakan tingkat signifikansi sebesar 0,006 lebih kecil dari tingkat signifikansi statistik sebesar 0,05 . Hal ini menunjukan bahwa $\mathrm{H}_{0}$ ditolak dan $\mathrm{H}_{1}$ diterima., sehingga dapat disimpulkan bahwa secara bersama-sama variabel komitmen $\left(\mathrm{X}_{1}\right)$, kualitas sumber daya manusia $\left(\mathrm{X}_{2}\right)$, perangkat pendukung $(\mathrm{X} 3)$ dan motivasi $\left(\mathrm{X}_{4}\right)$ berpengaruh terhadap pelaksanaan pelaporan pertanggungjawaban dana Gereja Masehi Injili di Minahasa. 
Tabel 5.19

Uji Statistik (Uji t)

Coefficients $^{\mathrm{a}}$

\begin{tabular}{|c|c|c|c|c|c|c|}
\hline \multirow{2}{*}{\multicolumn{2}{|c|}{ Model }} & \multicolumn{2}{|c|}{ Unstandardized Coefficients } & \multirow{2}{*}{$\begin{array}{c}\begin{array}{c}\text { Standardized } \\
\text { Coefficients }\end{array} \\
\text { Beta }\end{array}$} & \multirow[b]{2}{*}{$\mathrm{T}$} & \multirow[b]{2}{*}{ Sig. } \\
\hline & & B & Std. Error & & & \\
\hline \multirow[t]{5}{*}{1} & (Constant) & 19.921 & 4.659 & & 4.276 & .000 \\
\hline & $\mathrm{X} 1$ & .141 & .112 & .173 & 1.262 & .212 \\
\hline & $\mathrm{X} 2$ & .087 & .110 & .123 & .787 & .435 \\
\hline & $\mathrm{X} 3$ & .186 & .105 & .253 & 1.768 & .083 \\
\hline & $\mathrm{X} 4$ & -.156 & .110 & -.174 & -1.413 & .163 \\
\hline
\end{tabular}

a. Dependent Variable: Y

Sumber : data diolah, 2016

\subsection{Pengaruh Komitmen terhadap Penyusunan Laporan Pertanggungjawaban dana GMIM.}

Berdasarkan hasil Uji Regresi Berganda pada tabel 5.19, dalam menjawab hipotesis 2 penelitian, terlihat bahwa tingkat signifikasi variabel komitmen $\left(\mathrm{X}_{1}\right)$ adalah sebesar 0,212 lebih besar dari tingkat signifikansi statistic sebesar 0,05 . Hal ini menunjukan bahwa $\mathrm{H}_{0}$ diterima dan $\mathrm{H}_{1}$ ditolak. Sehingga dapat disimpulkan bahwa komitmen tidak berpengaruh terhadap penyusunan laporan pertanggungjawaban dana GMIM. Penelitian ini sejalan dengan penelitian Aidil (2010) yang menyimpulkan bahwa secara parsial variable komitmen tidak berpengaruh terhadap Kemampuan Penyusunan Laporan Keuangan Pemerintah Daerah (Studi Empiris pada pemerintah Kota Tebing Tinggi.

\subsection{Pengaruh Kualitas Sumber Daya Manusia terhadap Penyusunan Laporan Pertanggungjawaban dana GMIM. \\ Berdasarkan hasil Uji Regresi Berganda pada tabel 5.19, dalam menjawab hipotesis 3 penelitian,} terlihat bahwa tingkat signifikasi variabel kualitas sumber daya manusia $\left(\mathrm{X}_{2}\right)$ adalah sebesar 0,435 lebih besar dari tingkat signifikansi statistic sebesar 0,05. Hal ini menunjukan bahwa $\mathrm{H}_{0}$ diterima dan $\mathrm{H}_{1}$ ditolak. Sehingga dapat disimpulkan bahwa kualitas sumber daya manusia tidak berpengaruh terhadap penyusunan laporan pertanggungjawaban dana GMIM. Penelitian ini sejalan dengan penelitian Sulani (2009) yang menyimpulkan bahwa secara parsial variable variabel Sumber Daya Manusia tidak berpengaruh terhadap keberhasilan penerapan PP 24 tahun 2005 di Kabupaten Labuhan.

\subsection{Pengaruh Perangkat Pendukung terhadap Penyusunan Laporan Pertanggungjawaban dana GMIM. \\ Berdasarkan hasil Uji Regresi Berganda pada tabel 5.19, dalam menjawab hipotesis 4 penelitian,} terlihat bahwa tingkat signifikasi variabel perangkat pendukung $\left(\mathrm{X}_{3}\right)$ adalah sebesar 0,083 lebih besar dari tingkat signifikansi statistik sebesar 0,05 . Hal ini menunjukan bahwa $\mathrm{H}_{0}$ diterima dan $\mathrm{H}_{1}$ ditolak. Sehingga dapat disimpulkan bahwa perangkat pendukung tidak berpengaruh terhadap penyusunan laporan pertanggungjawaban dana GMIM. Hal ini sejalan dengan penelitian Terry (2013) yang mengatakan bahwa perangkat pendukung tidak berpengaruh terhadap penyusunan laporan keuangan pemerintah daerah. Hal ini disebabkan karena di Kabupaten Biak Numfor masih terbatas perangkat keras dan perangkat lunak, SKPD belum memiliki tenaga operator komputer dan perangkat pendukung yang ada sering mengalami kerusakan sehingga tidak dapat membantu proses penyusunan laporan keuangan.

\subsection{Pengaruh Motivasi terhadap Penyusunan Laporan Pertanggungjawaban dana GMIM.}

Berdasarkan hasil Uji Regresi Berganda pada tabel 5.19, dalam menjawab hipotesis 5 penelitian, terlihat bahwa tingkat signifikasi variabel Motivasi $\left(\mathrm{X}_{4}\right)$ adalah sebesar 0,163 lebih besar dari tingkat signifikansi statistik sebesar 0,05 . Hal ini menunjukan bahwa $\mathrm{H}_{0}$ diterima dan $\mathrm{H}_{1}$ ditolak. Sehingga dapat disimpulkan bahwa motivasi tidak berpengaruh signifikan terhadap pelaksanaan pelaporan pertanggungjawaban dana GMIM. Jadi meskipun para pegawai gereja memiliki motivasi yang baik, hal tersebut tidak berpengaruh signifikan terhadap pelaksanaan pelaporan pertanggungjawaban dana GMIM. Penelitian ini sejalan dengan penelitian Dermawan, dkk (2012) yang menyimpulkan bahwa Motivasi tidak berpengaruh signifikan terhadap peningkatan kinerja pegawai sehingga meskipun para pegawai yang bekerja 
di Dinas PU Provinsi Bali memiliki motivasi kerja yang baik, hal tersebut tidak berpengaruh signifikan atau memberikan pengaruh yang kecil terhadap kepuasan kerja yang dirasakan oleh para pegawai tersebut sehingga tidak berpengaruh signifikan terhadap peningkatan kinerja pegawai.

\section{BAB VI \\ KESIMPULAN DAN SARAN}

\subsection{Kesimpulan}

1. Komitmen, Kualitas Sumber Daya Manusia, Perangkat Pendukung dan Motivasi secara simultan berpengaruh signifikan terhadap pelaksanaan pelaporan pertanggungjawaban dana Gereja Masehi Injili di Minahasa (GMIM).

2. Komitmen secara parsial tidak berpengaruh signifikan terhadap pelaksanaan pelaporan pertanggungjawaban dana Gereja Masehi Injili di Minahasa (GMIM) di kota Manado. Dengan adanya komitmen dari para pengelola keuangan GMIM untuk memahami Tata Gereja GMIM serta semua peraturan yang dikeluarkan oleh BPMS maka pelaksanaan pelaporan pertanggungjawaban dana GMIM dapat terlaksana dengan baik dan dapat dipertanggungjawabkan.

3. Kualitas sumber daya manusia secara parsial tidak berpengaruh signifikan terhadap pelaksanaan pelaporan pertanggungjawaban dana GMIM. Pelatihan dan pengembangan sumber daya manusia secara berkelanjutan di tingkat pegawai pengelola keuangan di kantor jemaat, BIPRA dan Kolom dapat membantu para pelaksana pelaporan pertanggungjawaban dana gereja untuk menghasilkan laporan pertanggungjawaban dana yang baik dan dapat dipertanggungjawabkan. Selama ini yang ada hanya di tingkat pengurus BPMJ, dalam hal ini Bendahara Jemaat tetapi tidak tersosialisasikan kepada pengelola pertanggungjawaban dana gereja.

4. Perangkat pendukung secara parsial tidak berpengaruh signifikan terhadap penyusunan laporan pertanggungjawaban dana GMIM. Tersedianya perangkat komputer yang memadai di setiap gereja akan sangat membantu para pengelola keuangan dalam pelaporan pertanggungjawaban dana. Namun pada kenyataannya terdapat beberapa gereja tidak memiliki perangkat komputer yang memadai dan ada pula beberapa gereja yang memiliki perangkat computer namun sangat terbatas penggunaannya karena tidak memiliki aplikasi yang memadai untuk penyusunan laporan pertanggungjawaban dana dan juga sering mengalami kerusakan namun tidak memiliki tenaga operator komputer yang mampu mengatasi masalah kerusakan komputer.

5. Motivasi secara parsial tidak berpengaruh signifikan terhadap penyusunan laporan pertanggungjawaban dana GMIM. Meskipun para pengelola keuangan gereja memiliki motivasi kerja yang baik, hal tersebut tidak berpengaruh signifikan atau memberikan pengaruh yang kecil terhadap pelaksanaan pelaporan pertanggungjawaban dana gereja. Hal ini disebabkan karena para pengelola keuangan gereja melaksanakan pelaporan pertanggungjawabannya sesuai dengan keinginan masing-masing gereja tanpa memahami peraturan yang dikeluarkan oleh BPMS, selain itu kurangnya perhatian dari BPMS untuk memberikan pemahaman tentang pelaksanaan pelaporan pertanggungjawaban dana gereja yang baik.

\subsection{Saran}

1. Badan Pekerja Majelis Sinode (BPMS) mensosialisasikan dengan baik seluruh peraturan tentang pengelolaan keuangan gereja tidak hanya kepada para pengurus gereja tetapi juga kepada para pegawai sampai kepada jemaat pengurus komisi ARPIB (Anak, Remaja, Pemuda, Ibu, Bapak) dan kolom.

2. Mengadakan pelatihan dan pengembangan secara berkelanjutan baik di tingkat sinode, wilayah dan jemaat tentang pelaksanaan pelaporan pertanggungjawaban dana GMIM.

3. Menyediakan perangkat pendukung yang memadai dalam mendukung tersedianya laporan pertanggungjawaban dana yang rapi, teratur dan tepat waktu serta dapat dipertanggungjawabkan.

4. Motivasi untuk melayani dari para hamba Tuhan, pengurus dan pegawai gereja perlu ditingkatkan lagi, selain itu dukungan dari semua pihak baik para pelayan bahkan anggota jemaat sangat dibutuhkan serta dari BPMS yang merupakan pengambil kebijakan terkait pelaksanaan pelaporan pertanggungjawaban dana GMIM.

5. Mengadakan audit keuangan dan audit kinerja oleh auditor independen baik di tingkat Sinode, Wilayah dan Jemaat.

6. Untuk penelitian selanjutnya agar bisa memperluas objek penelitian seperti menambah objek gereja yang berbeda sehingga dapat dibandingkan dengan beberapa denominasi gereja. 


\section{DAFTAR PUSTAKA}

Aidil, 2010, Faktor-faktor yang Mempengaruhi Kemampuan Penyusunan Laporan Keuangan Pemerintah Daerah (Studi Empiris pada Pemerintah Kota Tebing Tinggi), USU, Medan

Azhar, 2007, Faktor-faktor yang Mempengaruhi Keberhasilan Penerapan Permendagri Nomor 13 Tahun 2006 pada Pemerintah Kota Banda Aceh USU, Medan.

Bastian I, 2010, Akuntansi Sektor Publik Suatu Pengantar edisi ketiga, Erlangga, Jakarta.

Berry, A. J, 2005, Accountability and Control In A Cat's Cradls, Accounting Auditing \& Accountability Journal, Vol. 18, No. 2, pp 255-297.

Buku Pedoman Penyusunan Tesis, Program studi Magister Akuntansi Fakultas Ekonomi Universitas Sam Ratulangi, 2011.

Chenly Ribka S. Pontoh, 2013, Penerapan Laporan Keuangan Organisasi Nirlaba Berdasarkan PSAK 45 pada Gereja BZL. Jurnal EMBA. Vol.1 No.3. (129-139). ISSN 2302-1174.

Dahnil Anzar dan Muhtar, 2010, Akuntansi dan Pengelolaan Keuangan di Masjid (sebuah studi kasus). Jurnal Publikasi. FE Universitas Sultan Ageng Tirtayasa.

Dermawan, dkk, 2012, Pengaruh Motivasi, Lingkungan Kerja, Kompetensi, Dan Kompensasi Terhadap Kepuasan Kerja Dan Kinerja Pegawai Di Lingkungan Kantor Dinas Pekerjaan Umum Provinsi Bali. FE Universitas Udayana.

Anak Agung Ngurah Bagus Dhermawan, I Gde Adnyana Sudibya, I Wayan Mudiartha Utama

Dina Nelma Sari dan Mariaty Ibrahim, 2014, Kemampuan Penyusunan Laporan Keuangan, Jurnal Administrasi Pembangunan, Volume 2, Nomor 3. FISIP Universitas Riau.

Fransiskus Randa,, 2011, Akuntabilitas Keuangan Dalam Organisasi Keagamaan (Studi Etnografi pada Sebuah Gereja Katolik di Tanah Toraja). Jurnal Sistem Informasi Manajemen dan Akuntansi. Vol.9, No. 2, Oktober 2011, (59-83).

Gereja Masehi Injili di Minahasa, 2007, Tata Gereja edisi 2007, Badan Pekerja Sinode Gereja Masehi Injili di Minahasa, Tomohon.

Hair, J. F. et al. 2010, Multivriate Data Analysis : A Global Prespective, $7^{\text {th }}$ edition. New Jersey: Person Prentice Hall

Halim, Abdul, 2007, Akuntansi dan Pengendalian Pengelolaan Keuangan Daerah, Edisi Revisi UPP STIM YKPN, Yogyakarta.

Handoko T. Hani, 2008. Manajemen Personalia dan Sumber Daya Manusia, edisi 3. Yogyakarta: BPFE.

Husein Umar, 2003, Metode Riset Akuntansi Terapan, Ghalia Indonesia, Jakarta.

Jensen, M, and W. Theory, Meckling, Of The Firm: Managerial (1976), Behavior,Agency "Cost and Ownership Strukture”. Journal Of Financial Economics, (3): 305-360.

Keraf, 2001, Komposisi (Kategori Bahasa dan Sastra), Nusa Indah, Surabaya.

Laughlin, R. C 1988, Accounting in Its Social Context : An Analysis of The Accounting System of the Church in England. Accounting, Auditing \& Accountability Journal, Vol. 1, No. 2, pp 19-42.

Laughlin, R. C 1990, A Model of Financial Accountibility and The Church of England. Financial Accountability \& Management, Vol. 6, No. 2, pp. 93-114.

Lightbody, M, 2000, Storing and Shielding : Financial Manajemen Behavior In A Church Organisation. Accounting, Auditing \& Accountability Journal, Vol. 13, No. 2, pp 156-174.

Maase. A, 2014, Pelaksanaan fungsi audit intern di organisasi nirlaba (Studi Kasus Pada GMIM Jemaat Kristus Manado), Unsrat, Manado.

Mahardika, Nur, Fakhururi, 2011, Pengaruh Sumber Daya Manusia, Motivasi, Pelatihan, Peraturann dan Sarana Pendukung terhadap Ketepatan Waktu Penyusunan Laporan Keuangan SKPD di Pemerintah Kota Malang, Unibraw, Malang.

Mardiyanto Handono, 2009, Intisari Manajemen Keuangan, Edisi pertama, Jakarta, Grasindo

Merystika Kabuhang, 2013 , Sistem Informasi Akuntansi Penerimaan dan Pengeluran Kas untuk

Perencanaan dan Pengendalian Keuangan pada Organisasi Nirlaba Keagamaan. Jurnal EMBA. Vol.1

No.3, Juni 2013. (339-348). ISSN 2302-1174. 